ISSN 2078-6441. Вісник Львівського університету. Серія географічна. 2013. Випуск 41. С. 205-212. Visnyk of the Lviv University. Series Geography. 2013. Issue 41. P. 205-212.

$911.2: 574.45: 574.472$

LANDSAT 7 ETM+

\author{
лекс ндр кртчян \\ ввівський н ціон льний університет імені вн \\ вул. . орошенк, 41, 79000, м. ввів, кр їн
}

озглянуто методику т результ ти цифрового н лізу мультиспектр льного космознімк LANDSAT 7 ETM+, що поляг в у обчисленні індексу NDVI т виділенні головних компонентів зобр ження. ро н лізов но зміст цих компонент ун слідок обчислення їхніх кореляцій зі спектр льними к н л ми т зв'язків з поширенням основних типів рослинного покриву.

лючові слов : мультиспектр льні геозобр ження, вегет ційний індекс, н ліз головних компонентів, геоінформ ційний н ліз.

риродоохоронн діяльність і просторове пл нув ння природокористув ння в гірських р йон х потребують дет льної просторової інформ ції про розподіл х р ктеристик природних умов і ресурсів. трим ння т кої інформ ції передб ч є проведення трудомістких і трив лих польових спостережень, моніторингових досліджень, к ртогр фічних робіт. появою і поширенням супутникових технологій дист нційного зондув ння емлі з'явились можливості отрим ння опер тивної, дет льної в просторі т доступної 3 ціною просторової інформ ції про ст н земної поверхні. г то супутникових зобр жень емлі нині містяться у цифрових рхів х і доступні в мережі нтернет, у тому числі безкоштовно. роте супутникові зобр ження з змістом є непрямими д ними, що підляг ють інтерпрет ції для отрим ння екологічно зн чимої т корисної в пр ктиці інформ ції.

ехнологію одерж ння цифрових мультиспектр льних супутникових зобр жень емлі екологічного призн чення розробляють чотири десятиліття, від з пуску в липні 1972 р. першого супутник мерик нської прогр ми LANDSAT. цей ч с н явний суттєвий прогрес у з соб х опр цюв ння т н лізу цифрових супутникових зобр жень. н чною мірою цей прогрес зумовлений розвитком технологій комп'ютерного опр цюв ння т н лізу зобр жень. ст ннім ч сом н мітил сь тенденція інтегр ції цих технологій з технологіями геогр фічних інформ ційних систем ( ): більшість суч сних

-п кетів містить прогр мні з соби для роботи з дист нційними зобр женнями.

йпоширенішим способом цифрового н лізу д них дист нційного зондув ння дист нційних зобр жень емлі, є їхня кл сифік ція, як передб ч $є$ втом тизов не виділення з знімком контурів дискретних об'єктів: земельних угідь, типів н земного покриву, деревост нів, водних об'єктів тощо. нші види н лізу в кр їні сьогодні з стосовують н б г то рідше, проте деякі з них м ють зн чний потенці л щодо розкриття 3 кономірностей просторової структури рослинного покриву т землекористув ння, дослідження їхньої ч сової дин міки. дним із т ких методів є обчислення спектр льних індексів 3 відповідними формул ми. пектр льний індекс-це певн м тем тичн комбін ція зн чень відбивної зд тності земної поверхні в деяких спектр льних ді п зо-

(C) кртчян ., 2013 
H х, як х р ктеризує деякий комплекс вл стивостей л ндш фту. дним з н йвідоміших і одноч сно н йпростіших з формою є норм лізов ний вегет ційний індекс (NDVI), який обчислюють 3 формулою NDVI = (NIR - RED) / (NIR + RED), де NIR - відбивн зд тність у ближньому інфр червоному ді п зоні; $R E D$ - відбивн зд тність у червоному ді п зоні спектр [7]. ідомо, що зелені рослини добре поглин ють червоні промені, які вони використовують для фотосинтезу, проте відбив ють інфр червоні промені для 3 хисту від перегрів ння. тже, чим більше зн чення цього індексу, тим інтенсивніше відбув ється процес фотосинтезу і тим ліпшим є екологічний ст н природної бо культурної рослинності: у р зі пошкодження рослинності хвороб ми, шкідник ми, хімічними речовин ми зн чення цього індексу, з звич й, зменшується. тже, цей індекс х р ктеризує інтенсивність фотосинтезу, біологічну продуктивність екосистем, ступінь розвинутості й ст н н земної фітом си. озроблено й низку інших спектр льних індексів, які х р ктеризують вміст вологи в зеленій фітом сі, вміст 3 ліз в грунт х т гірських пород $\mathrm{x}$, потужність снігового покриву тощо.

е одним цік вим н літичним методом отрим ння інформ ції $€$ н ліз головних компонентів мультиспектр льного зобр ження. н ліз головних компонентів визн ч ють як “лінійний метод зниження розмірності, у якому визн ч ють поп рно ортогон льні н прями м ксим льної в рі ції вихідних д них, після чого д ні проектують н простір меншої розмірності, який породжений компонент ми з н йбільшою в рі цією” (Bishop, 1995, з [8]). з стосув нні до мультиспектр льних дист нційних зобр жень емлі н ліз головних компонентів поляг є у виділенні нез лежних компонентів просторової в рі бельності відбивної зд тності земної поверхні. ідбивн зд тність у різних спектр льних ді п зон х, з звич й, корелює між собою. ерез це мультиспектр льні зобр ження (н прикл д, вісім спектр льних к н лів мультиспектр льних зобр жень системи LANDSAT TM) містять н длишкову інформ цію. ю інформ цію нерідко можн звести до меншої кількості (три - чотири) вз ємно некорельов них (ортогон льних) зобр жень з мінім льною втр тою сукупної інформ ції, що міститься в усіх спектp льних к н л х. цьому р зі отрим ні ортогон льні зобр ження міститимуть в жливу інформ цію про структуру н земного покриву, як нерідко є неочевидною у вип дку візу льного огляду т н лізу первинних зобр жень.

ифрові моделі рельєфу ( ) сьогодні широко використовують у геоекологічних т л ндш фтно-екологічних дослідженнях для х р ктеристики особливостей морфометрії земної поверхні. они, зокрем , д ють змогу в середовищі досить легко і швидко обчислюв ти пок зники похилів поверхні, експозиції, вертик льного розчленув ння, т кож скл дніші н літичні пок зники, які х р ктеризують перерозподіл вологи, сонячної енергії т твердої речовини під впливом рельєфу і гр віт ції [2]. одібно до мультиспектр льних дист нційних зобр жень, нині більшість отримують 3 допомогою супутникових технологій, т ких як р д рн інтерферометрія т л зерн льтиметрія. Д ють змогу н кл д нням (оверлеєм) мультиспектр льних зобр жень (i отрим них з них похідних зобр жень т індексів) т (і отрим них з них похідних пок зників) н лізув ти просторові зв'язки т 3 лежності між х р ктеристик ми ектоярусу л ндш фту (що індикують ст н рослинного т техногенного покриву, водних об'єктів, рідше - грунтів т гірських порід) т морфометричними х р ктеристик ми земної поверхні.

ериторія н шого дослідження - це прямокутн ділянк розмір ми 90×70 км, розміщен в центр льній ч стині кр їнських рп т. і гон ль прямокутник приблизно відповід є осі к рп тської дуги, отже, ділянк охоплює північний і південний м кро- 
схили рп т т (північний схід ділянки) ч стину ередк рп ття. ке розт шув ння ділянки д ло змогу включити до неї низку різном нітних з л ндш фтного погляду структурно-тектонічних зон. ілянк досліджень охоплює т кі фізико-геогр фічні обл сті: ередк рп тську височинну, овнішньок рп тську, ододільноверховинську, олонинсько- орногірську т улк нічно-міжгірно-улоговинну [3].

жерел ми д них слугув ли мультиспектр льні дист нційні зобр ження LANDSAT 7 ETM+ т SRTM v. 4.1. обр ження LANDSAT 7 ETM+ отрим не 3 онл йнового pхіву USGS (http://glovis.usgs.gov). оно скл д ється з восьми ф йлів, що відповід ють вісьмом спектр льним к н л м: 1) 0,45-0,52 (синій); 2) 0,52-0,6 (зелений); 3) 0,63-0,69 (червоний); 4) 0,76-0,90 (ближній інфр червоний); 5) 1,55-1,75 (середній інфр червоний); 6) 10,5-12,5 (терм льний інфр червоний); 7) 2,08-2,35 (середній інфр червоний); 8) 0,52-0,90 (п нхром тичний). нім ння виконув ли 13 жовтня 2009 p. і зобр ження м ють просторову роздільність 30 м, у проекції UTM (еліпсоїд WGS84).

SRTM v. 4.1 отрим н 3 онл йнового рхіву онсорціуму просторової інформ ції CGIAR (http://srtm.csi.cgiar.org). ихідні д ні - у геогр фічній координ тній системі (еліпсоїд WGS84), з просторовою роздільністю близько 90 м.

ервинне опр цюв ння д них поляг ло у зведенні їх до спільної системи координ т т просторової роздільності. ля цього SRTM v. 4.1 спроектов но в координ тну систему UTM, мультиспектр льне зобр ження LANDSAT 7 ETM+ проріджено до просторової роздільності 90 м.

озподіл індексу NDVI обчислено з н веденою вище формулою, з використ нням спектр льних к н лів 3 т 4 мультиспектр льного зобр ження LANDSAT 7 ETM+. трим ну к рту пок $з$ но н рис. 1 .

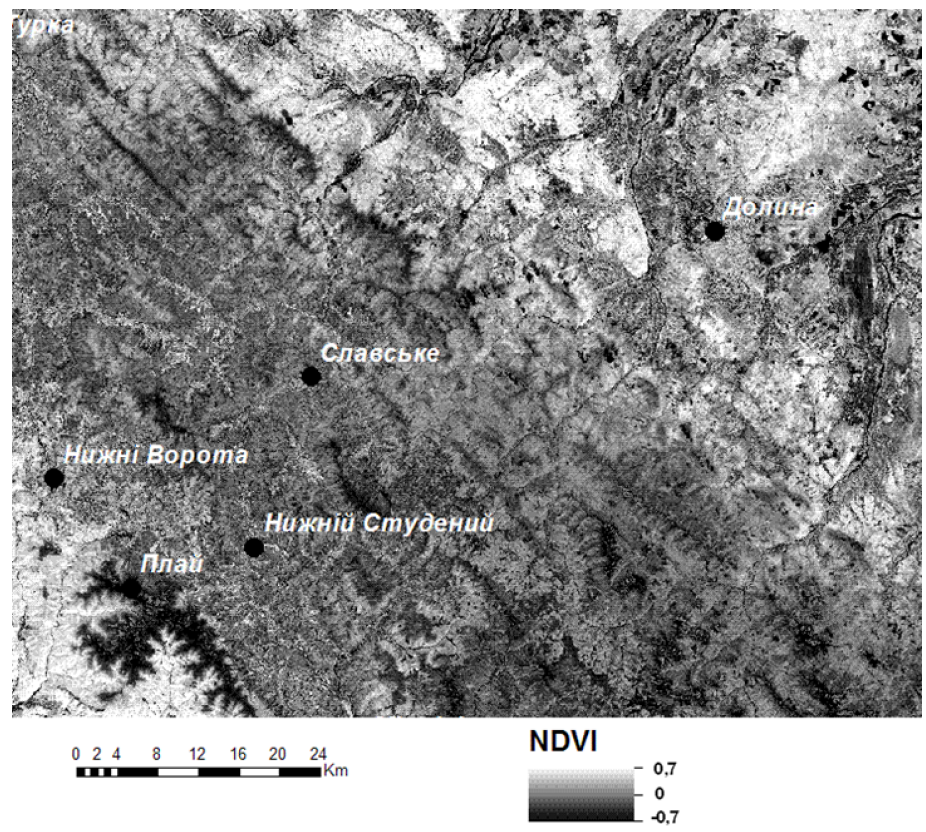

ис. 1. озподіл зн чень індексу NDVI в меж х території досліджень. 
ожн поб чити, що н йвищі зн чення цього індексу (світліші відтінки н зобр женні) вл стиві широколистяним (н с мперед буковим) ліс м, поширеним у передгір'ях, т кож н південному м кросхилі гір (лівий нижній кут зобр ження). йнижчі зн чення прит м нні гірським полонин м (н прикл д, полонині орж в ), т кож водним поверхням, з будов ним територіям, орним угіддям. роміжні зн чення (сірі відтінки н зобр женні) х р ктерні для хвойних т міш них з перев ж нням смереки лісів, поширених н північно-східному м кросхилі рп тських гір.

рубіжні вчені виявили зв'язки між зн ченнями індексу NDVI т пок зник ми видової різном нітності флори [4] і ф уни [6]. кож виявлено зв'язок між зн ченнями цього індексу т зд тністю екосистем поглин ти з тмосфери й утримув ти вуглець [5]. тже, високі зн чення індексу NDVI можн вв ж ти чинником, що свідчить про функціон льну цінність екосистем. е, зокрем, доцільно вр ховув ти в пл нув нні природоохоронної діяльності в р зі визн чення пріоритетності територій, яким н д ють природоохоронний ст тус.

рис. 2 зобр жено ді гр му, що демонструє зв'язок між зн ченнями індексу NDVI т пок зник ми бсолютної висоти й похилів поверхні (крутості схилів) у меж х досліджув ної території. ї отрим но вн слідок оверлейного н лізу зн чень індексу NDVI, зіст влених у просторі зі зн ченнями бсолютної висоти т похилів поверхні. к 6 чимо з ді гр ми, високі зн чення індексу NDVI, з звич й, вл стиві місцеположенням н крутих і сп дистих схил х н нижчих бсолютних висот х (до 500-600 м н д рівнем моря). е треб вр ховув ти в р зі визн чення пріоритетності територій, яким н д ють природоохоронний ст тус: доцільно розширити мережу природоохоронних територій у поясі низькогірних букових лісів.

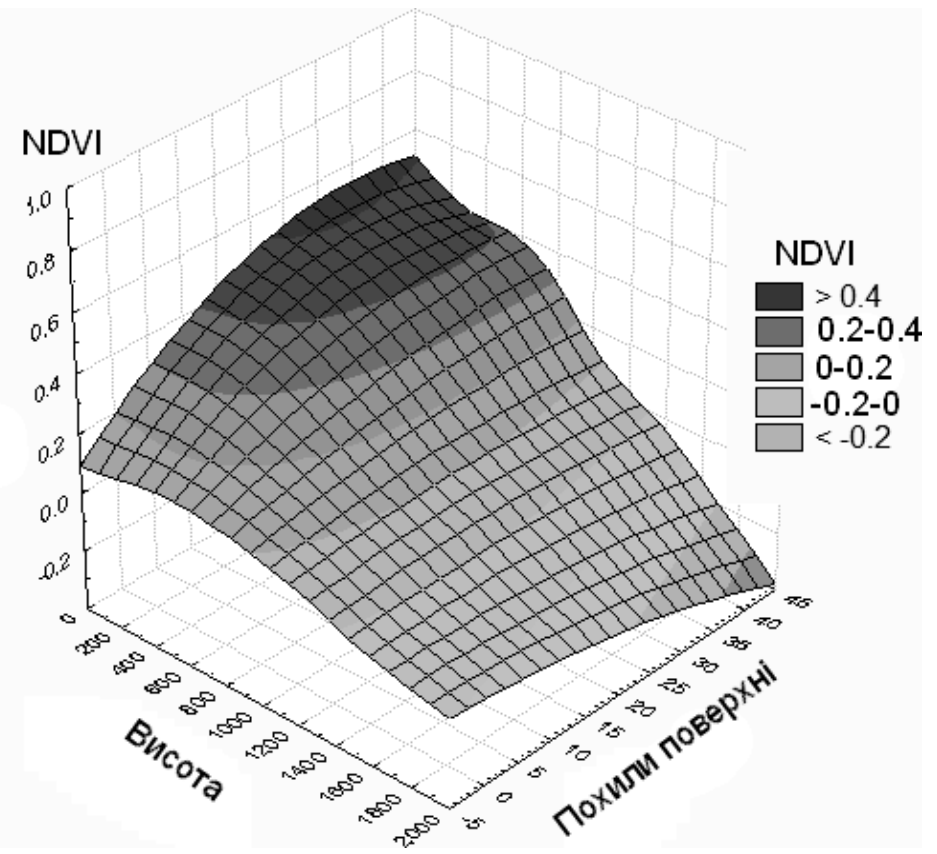

ис. 2. в'язок між зн ченнями індексу NDVI т пок зник ми рельєфу території досліджень. 
н ліз головних компонентів д в змогу виділити нез лежні компоненти просторової в рі ції, які р зом відобр ж ють структуру зв'язків між відбивною зд тністю земної поверхні в різних спектр льних ді п зон х. езульт ти цього н лізу н ведені в т бл. 1,2. окрем , виявилось, що перші три головні компоненти р зом відобр ж ють 99,91 \% з г льної дисперсії (просторової мінливості) восьми вихідних спектр льних к н лів мультиспектр льного зобр ження (т бл. 1). он д 3/4 3 г льної дисперсії перед є перший компонент.

т бл. 2 н ведено коефіцієнти кореляції відбивної зд тності в спектр льних к н л х 2-5 із головними компонент ми. е певною мірою д $€$ змогу судити про зміст виділених головних компонентів. прикл д, перший компонент нег тивно корелює $з$ усім чотирм спектр льними к н л ми, із доволі високим коефіцієнтом кореляції. тже, він відповід є з г льній “яскр вості” поверхні: більші зн чення яскр вості відповід ють меншим зн ченням цього компонент .

ізу льний н ліз просторової структури цього компонент (рис. 3) т його зіст влення з топогр фічними к рт ми території виявили його досить тісний зв'язок із н явністю т щільністю деревост нів.

блиця 2 ругий компонент, н томість,

оефіцієнти кореляції

між деякими спектр льними к н л ми

т головними компонент ми

\begin{tabular}{|c|c|c|c|c|}
\hline $\begin{array}{c}\text { пектр ль- } \\
\text { ний к н л }\end{array}$ & $\begin{array}{c}\text { овжин } \\
\text { хвилі, } \\
\text { мкм }\end{array}$ & $\begin{array}{c}\text { омпо- } \\
\text { нент 1 }\end{array}$ & $\begin{array}{c}\text { омпо- } \\
\text { нент 2 }\end{array}$ & $\begin{array}{c}\text { омпо- } \\
\text { нент 3 }\end{array}$ \\
\hline $\mathbf{2}$ & $0,52-0,60$ & $-0,95$ & $-0,18$ & 0,23 \\
\hline $\mathbf{3}$ & $0,63-0,69$ & $-0,89$ & $-0,45$ & 0,06 \\
\hline $\mathbf{4}$ & $0,76-0,90$ & $-0,70$ & 0,70 & 0,15 \\
\hline $\mathbf{5}$ & $1,55-1,75$ & $-0,91$ & 0,09 & $-0,41$ \\
\hline
\end{tabular}

блиця 1

л сні зн чення головних компонентів т їхній внесок у з г льну дисперсію

\begin{tabular}{|c|c|c|}
\hline омпонент & $\begin{array}{c}\text { л сне } \\
\text { зн чення }\end{array}$ & $\begin{array}{c}\text { г льн } \\
\text { дисперсія, \% }\end{array}$ \\
\hline $\mathbf{1}$ & 3,01 & 75,22 \\
\hline $\mathbf{2}$ & 0,73 & 18,18 \\
\hline $\mathbf{3}$ & 0,25 & 6,21 \\
\hline
\end{tabular}
ційним індексом NDVI. тже, другий компонент н с мперед розрізняє широколистяні ліси, які м ють високу біологічну продуктивність т високе біорізном ніття. кож цей компонент ліпше диференціює різні типи землекористув ння й нтропогенних н земних покривів (рис. 4). г лом його можн інтерпретув ти як т кий, що х р ктеризує рівень біологічної продуктивності екосистем.

ретій головний компонент - менш інформ тивний порівняно з першими двом i вiдобр ж є менші зн чення кореляції з більшістю спектр льних к н лів. роте візу льний н ліз виявив, що високі зн чення цього компонент збіг ються в просторі з р йон ми поширення суб льпійських лук. ому цей компонент можн використовув ти в к ртув нні т моніторингу поширення цінних з екологічного погляду суб льпійських угрупов нь зі зн чною кількістю рідкісних видів флори. 


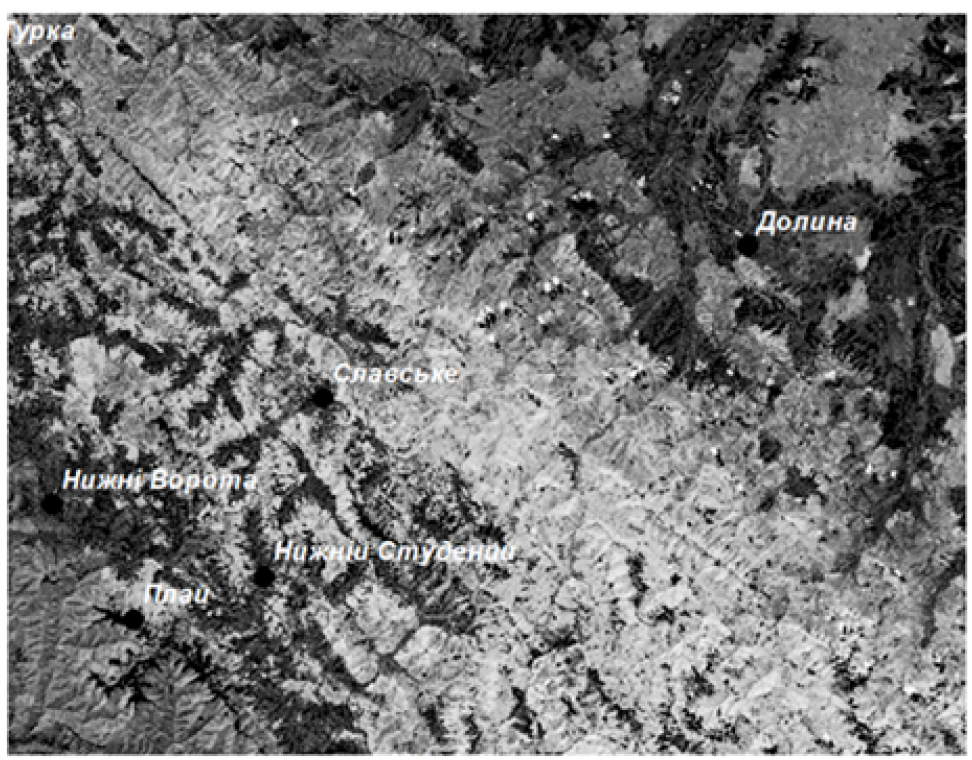

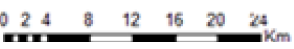

ис. 3. росторов структур першого головного компонент .
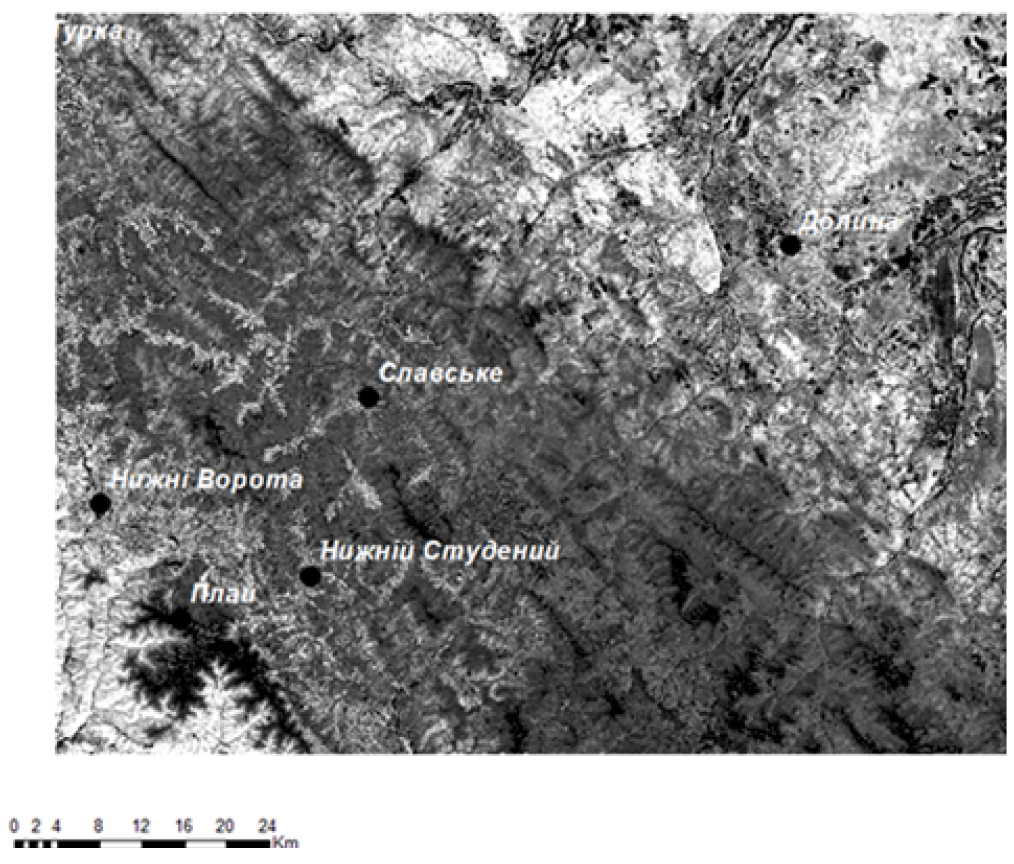

ис. 4. росторов структур другого головного компонент . 
тже, цифровий н ліз дист нційних зобр жень емлі д є змогу отрим ти в жливу в н уковому і пр ктичному пл ні інформ цію щодо особливостей просторової структури н земного покриву, розподілу низки в жливих х р ктеристик екосистем.

ю інформ цію можн використ ти в пл нув нні природоохоронної діяльності т моніторингу ст ну н земних екосистем і х р ктеру землекористув ння. оловними скл дник ми просторової в рі ції відбивної зд тності земної поверхні в меж х ділянки центр льної ч стини кр їнських рп т виявились: 1) з г льн яскр вість земної поверхні в усіх спектр льних к н л х, як нег тивно корелює з присутністю і щільністю деревної рослинності; 2) компонент, що тісно корелює з відомим вегет ційним індексом NDVI т диференціює широколистяні деревост ни, т луки і хвойні, нерідко - вторинні деревост ни.

\section{СПИСОК ВИКОРИСТАНОЇ ЛІТЕРАТУРИ}

1. озлов . . нвент риз ция л ндш фтного покров метод ми простр нственного н лиз для целей л ндш фтного пл ниров ния / . озлов // ндш фтное пл ниров ние: общие основ ния, методология, технология. руды еждун родной школы-конференции “ ндш фтное пл ниров ние”. - . : еогр. ф-т оск. ун-т , 2006. - . 117-137.

2. кртчян . . оль цифрових моделей рельєфу в геоекологічних дослідженнях / . . кртчян // еогр фія в інформ ційному суспільстві : зб. н ук. пр ць. 4 т. . : брії, 2008. - .67-69.

3. ізико-геогр фічне р йонув ння. рт // ціон льний тл с кр їни. - . : тогр фія, 2009. - . 228-229.

4. Bawa K. Assessing biodiversity from space: an example from the Western Ghats, India / K. Bawa, J. Rose, K. N. Ganeshaiah, N. Barve, M. C. Kiran, R. Umashaanker // Conservation Ecology. - 2002. - N 6 (2). - ежим доступу: http://www.consecol.org/vol6/iss2/art7.

5. Frank A. Vegetation indices, $\mathrm{CO} 2$ flux, and biomass for Northern Plains grass-lands / A. Frank, J. Karn // J. of Range Management. - 2003. - N 56. - P. 382-387.

6. Oindo B. O. Interannual variability of NDVI and bird species diversity in Kenya / B. O. Oindo, R. A. de By, A. K. Skidmore // International J. of Applied Earth Observation and Geoinformation. - 2000. - N 2 (3-4). - P. 172-180.

7. Rouse J. W. Monitoring vegetation systems in the Great Plains with ERTS / J. W. Rouse, R. H. Haas, J. A. Schell, D. W. Deering // Third ERTS Symposium. NASA SP-351 (I). 1973. - P. 309-317.

8. StatSoft, Inc. лектронный учебник по ст тистике. - . . StatSoft, 2001. - ежим доступу: http://www.statsoft.ru/home/textbook/default.htm.

m ття: н дійшл до ред кції 24.09.2012

доопр цьов н 17.12.2012

прийнят до друку 20.02.2013 


\title{
DIGITAL ANALYSIS OF MULTISPECTRAL SPACE IMAGERY LANDSAT 7 ETM+ OF THE AREA IN CENTRAL PART OF UKRAINIAN CARPATHIANS
}

\section{Olexandr Mkrtchian}

Ivan Franko National University of Lviv, P. Doroshenko St., 41, UA - 79000 Lviv, Ukraine

The methodology and results of the digital analysis of multispectral space imagery LANDSAT 7 ETM+ are considered, namely the calculation of NDVI index and isolation of principal components. The meaning of the latter has been analyzed by the calculation of their correlations with spectral channels and relations to the main vegetation types.

Key words: multispectral geoimagery, vegetation index, principal component analysis, geoinformation analysis.

\section{LANDSAT 7 ETM+}

лекс ндр кртчян

\author{
ьвовский н иион льный университет имени в н \\ ул. орошенко, 41, 79000, г. ввов, кр ин
}

ссмотрено методику и результ ты цифрового н лиз мультиспектр льного космоснимк LANDSAT 7 ETM+, состоящего в р счете индекс NDVI и выделении гл вных компонент изобр жения. ро н лизиров но содерж ние компонентов путем р счет их корреляций со спектр льными к н л ми и связей с р спростр нением основных типов р стительного покров .

лючевые слов : мультиспектр льные геоизобр жения, вегет ционный индекс, н лиз гл вных компонент, геоинформ ционный н лиз. 